\title{
RAPTORS NESTING IN WASCANA PARK, REGINA
}

JARED B. CLARKE, \#3-2144 Rose Street, Regina SK, S4P 2A4, E-mail: <clarkejared16@yahoo.ca>

Over 25 different species of raptors have been documented nesting within urban centres across the globe. ${ }^{6}$ In an urban setting, raptors benefit from concentrated food supplies, "good" potential nesting sites, and shelter from predators. ${ }^{6}$ However, they also face novel challenges such as increased exposure to collisions with vehicles and buildings, pigeon poisoning, and disturbances such as building and city maintenance. ${ }^{6}$ As a result of these challenges, some urban-nesting raptors have lower fledging success compared to their rural counterparts. ${ }^{1,2}$

In Saskatchewan, at least six raptor species have previously been documented as nesting within urban centres. These include, in addition to the ones reported here, Long-eared Owl, (see photograph by Morag Granger on page 177 in September
2008 Blue Jay) and Peregrine Falcon. ${ }^{3,4,5,7}$ During the 2008 breeding season, I documented nesting by Cooper's Hawks, Great Horned Owls, American Kestrels and Merlins in Wascana Park within Regina. Here I present the outcome of these nests and compare the fledging success between these urban nests to rural nests I located during the same breeding season.

\section{Cooper's Hawk (Figure 1)}

This is the fifth year that Cooper's Hawks have been found nesting in Wascana Park since 2003. In 2006, I banded both adults with redalphanumeric bands. On 7 May 2008, Joseph Kotlar and I observed the same pair building a nest $14.3 \mathrm{~m}$ above the ground in an American Elm near the Royal Saskatchewan Museum. On 23 May, an adult was observed in an incubating position.

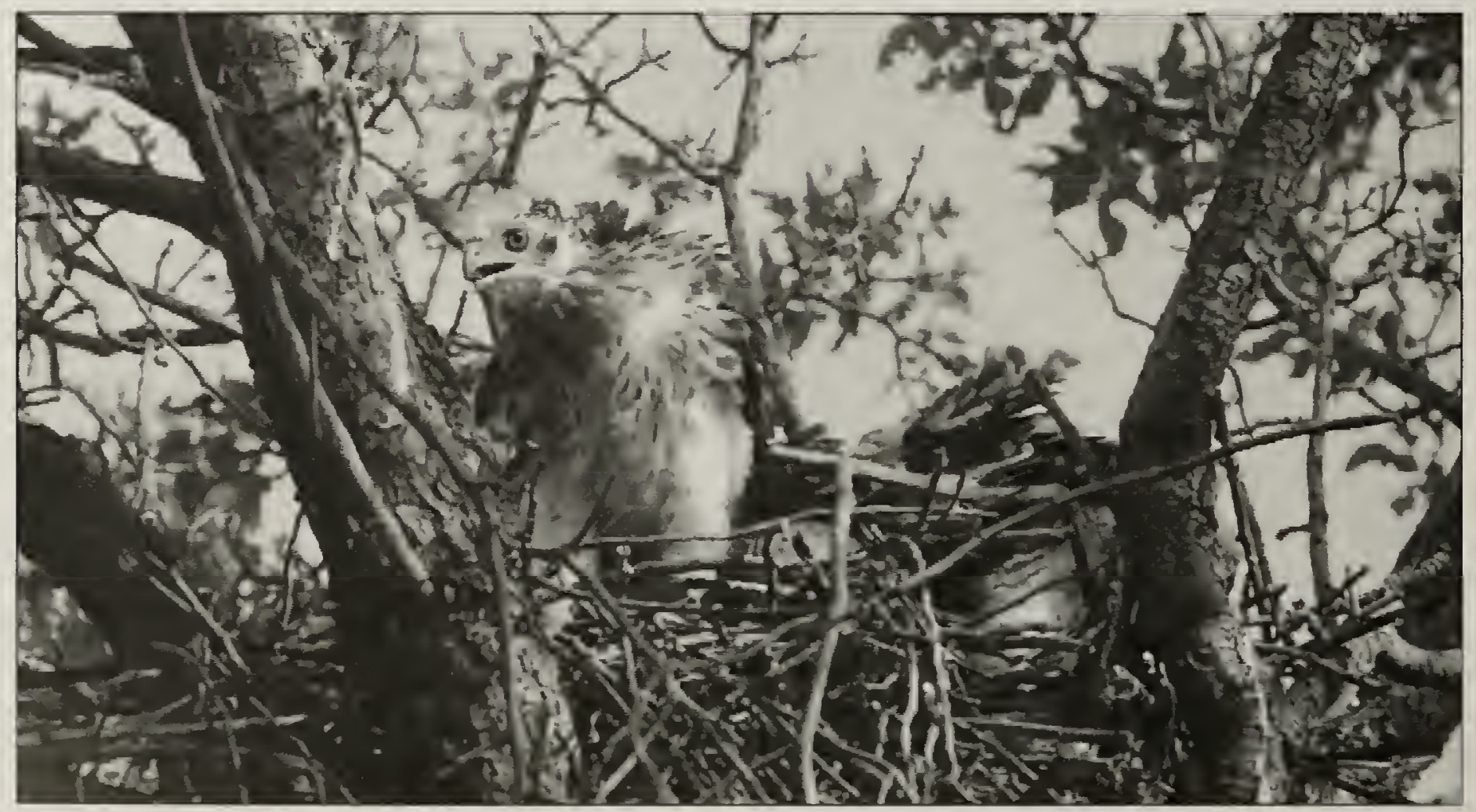

Figure 1. Cooper's Hawk chicks in nest in Wascana Park, Regina.

J. Clarke 


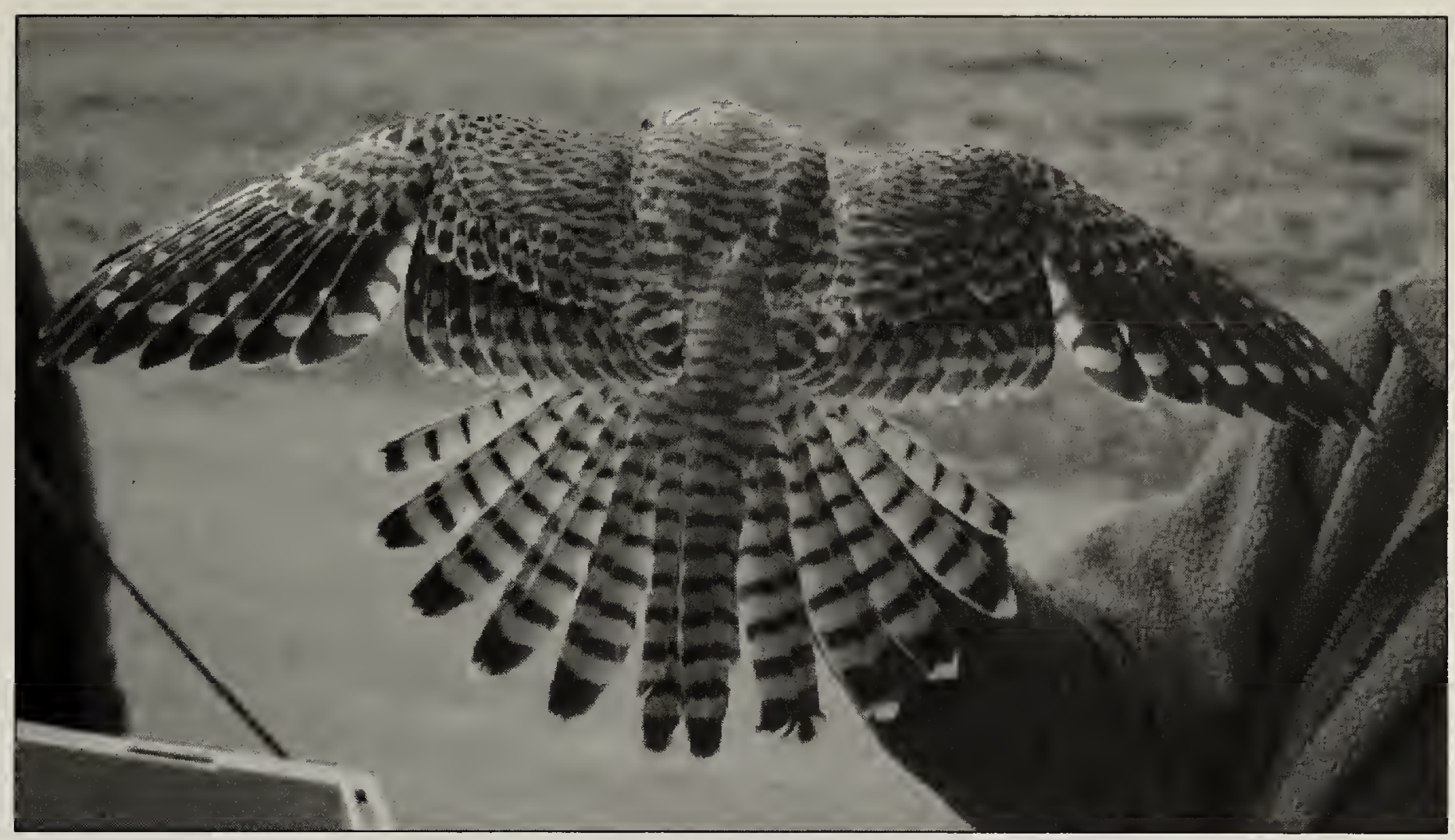

Figure 2. Adult female American Kestrel banded at nest box \#25.

J. Clarke

On 14 July, three chicks about 23 days old were present in the nest: two females and one male, which were banded. By 31 July, all three chicks had fledged and were within $100 \mathrm{~m}$ of the nest. All three chicks were still present in the area of the nest as of 12 August. On 21 August only one chick was still near the nest. The rural nests I visited this year had comparable clutches of young ( 3.5 chicks fledged/ nest, $n=2$ ).

\section{Great Horned Owl}

On 26 April 2008, a Great Horned Owl nest was found in Wascana Park, about $5 \mathrm{~m}$ from the edge of Albert Street, $12.1 \mathrm{~m}$ from the ground in a spruce tree. Only one other nesting attempt by this species has been noted in the park (Bob Ewart and Lorne Scott, pers comm.). Joseph Kotlar and I banded the single nestling on 7 May. I did not continue intensively monitoring the nest but received a report that a fledgling Great Horned Owl was observed flying near the nest after I noticed the nest was empty. With the nest so close to Albert St. I was worried that the chick would be unintentionally startled into traffic and struck by a vehicle. However, there was no recovery of its band nor any sign of a dead owl on Albert Street during the summer. This nest had low productivity compared to rural sites (2.01 chicks/nest at the time of visit, $\mathrm{n}=72$ ).

\section{American Kestrel (Figure 2)}

Two of three nest boxes designed for American Kestrels in Wascana Centre were occupied by kestrels in 2008. Nest box \#25 sits on an old telephone pole near the entrance to the Wascana Country Club, near the old Plains Hospital. (While this area is not typically associated with Wascana Park, it is owned by the Wascana Centre Authority and is therefore part of the park.) On 23 April 2008 , an adult female kestrel was captured and banded at this nest, while she incubated five eggs. Five chicks, three females and two males, were banded on 9 June and fledged ten days later.

Nest box \#31, also on a telephone pole, was situated at the Wascana 


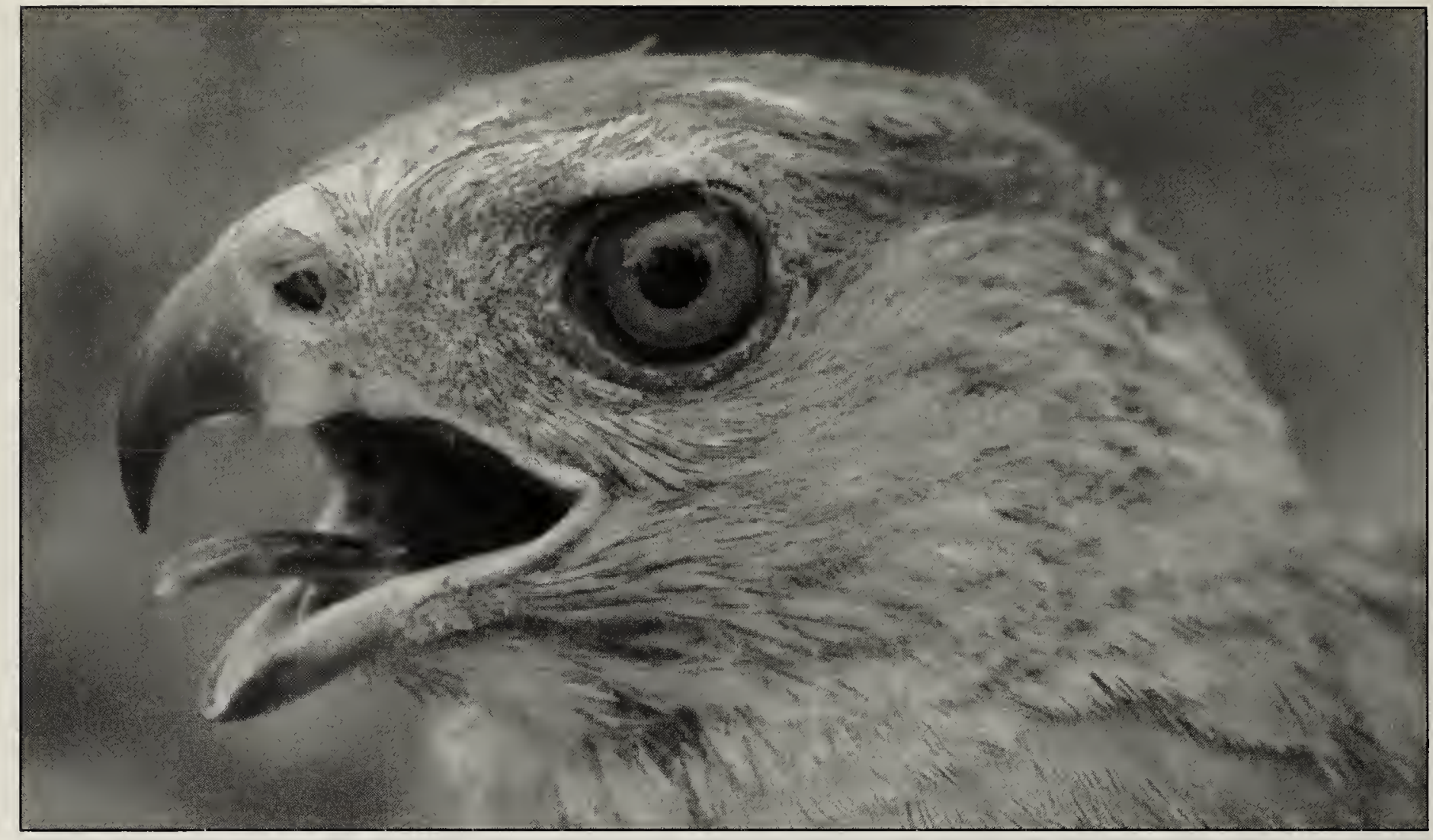

Adult female Cooper's Hawk banded 15 July 2006, at Roche Percee

J. Clarke

Centre Authority greenhouse, south of Douglas Park. I was unable to check the box until after the chicks had hatched. This nest was possibly a renesting attempt as it was quite late. On 18 June the chicks were only one week old, compared to the chicks in Nest box \#25 that were fledging at this time. On 8 July, four female nestlings were banded a few days before fledging. These two urban nests fledged slightly more chicks than their rural counterparts (3.8 chicks fledged Inest, $\mathrm{n}=5$ ).

\section{Merlin}

There were two nesting attempts made by this species although the outcomes were not determined. One pair was present at a nest site that was also used in 2007 behind the Legislative building, and gave alarm calls as I approached the nest late in June when chicks should have been present. The second nest was in the large spruce trees in the parking lot of the T. C. Douglas building on Albert St and 23rd Avenue. The outcome of this nest also was not determined.

\section{Acknowledgements}

Thanks to all who helped locate and monitor these nests, as well as those who assisted while banding.

1. BOAL, C.W. 1997. An urban environment as an ecological trap for Cooper's Hawks. Ph.D dissertation., University of Arizona, Tucson, AZ.

2. ENGLAND, A.S., J.A. ESTEP, and W.R. HOLT. 1995. Nest-site selection and reproductive performance of urban-nesting Swainson's Hawks in the Central Valley of California. Journal of Raptor Research 29:179-186.

3. JAMES, P.C. 1992. Urban-nesting of Swainson's Hawks in Saskatchewan. Condor 94:773-774.

4. KOZIJ, K. 2003. Urban-nesting Merlins and Cooper's Hawks in Weyburn, SK. Blue Jay 61: 33-38.

5. LEIGHTON, A., J. HAY, C.S. HOUSTON, J.F. ROY, and S. SHADICK. 2002. Birds of the Saskatoon area. Special Publication \#23, Saskatchewan Natural History Society, Regina.

6. LOVE, O.P., and D.M. BIRD. 2000. Raptors in urban landscapes: A review and future concerns. In Chancellor, R.D., and B.-U. Meyburg, (eds.) Raptors at Risk. WWGBP, London. 425-434.

7. STOFFEL, M.J., and C.S. HOUSTON. 2004. First Swainson's Hawk breeding in residential Saskatoon. Blue Jay 62: 112-113. 